\title{
Dynamic simulation of an opencast coal mine: a case study
}

\author{
Kesavan Muniappen ${ }^{1} \cdot$ Bekir Genc $^{1}$ (B)
}

Received: 13 August 2019/Revised: 13 October 2019/Accepted: 5 December 2019/Published online: 13 December 2019

(C) The Author(s) 2019

\begin{abstract}
Dynamic simulations are powerful tools, but only if they are developed using the correct methodology, and with information that has been verified. Mining houses rely on simulation to confirm that complex, integrated systems can achieve design capacity before investment decisions are made. Work conducted in the realm of validation can make an invaluable contribution to the success of future projects undertaken around the world. Coal mine a life of mine extension project was approved for implementation when export coal prices were on the low end of the price cycle. The dynamic simulation of the full materials handling value chain conducted during the project feasibility study in 2016 was of utmost importance and provided assurance to the project review team that annual production targets can be achieved. The simulation development methodology was based on a unique approach that reduced time spent on the simulation. Upon completion of project construction and commissioning in 2018, it was essential to validate the simulation, which could lead to the adoption of this approach on future projects. This paper explains the steps taken to validate the dynamic simulation. This case study confirmed that dynamic simulation can add value and predict mining system performance, such that informed decisions can be made.
\end{abstract}

Keywords Simulation $\cdot$ Gensym G2 System performance $\cdot$ Life of mine $\cdot$ Coal mining

$\begin{array}{ll}\text { Abbreviations } \\ \text { Ad } & \text { Air dry } \\ \text { BMH } & \text { Bulk materials handling } \\ \text { CCR } & \text { Critical constrained resource } \\ \text { COT } & \text { Coaling operating time } \\ \text { DMS } & \text { Dense medium separation } \\ \text { DOT } & \text { Direct operating time } \\ \text { FEL } & \text { Front end loader } \\ \text { FTP } & \text { Feed to plant } \\ \text { GPSS } & \text { General purpose simulation system } \\ \text { LOM } & \text { Life of mine } \\ \text { M\&S } & \text { Modelling and simulation } \\ \text { MS } & \text { Microsoft } \\ \text { MT } & \text { Million tonnes }\end{array}$

Bekir Genc

bekir.genc@wits.ac.za

1 School of Mining Engineering, University of the Witwatersrand, Johannesburg, South Africa

$\begin{array}{ll}\text { Mtpa } & \text { Million tonnes per annum } \\ \text { MTTR } & \text { Mean time to repair } \\ \text { ROM } & \text { Run of mine } \\ \text { SCADA } & \text { Supervisory control and data acquisition } \\ \text { t } & \text { Tonnes } \\ \text { TOC } & \text { Theory of constraints } \\ \text { t/d } & \text { Tonnes per day } \\ \text { t/h } & \text { Tonnes per hour } \\ \text { vs } & \text { Versus }\end{array}$

\section{Introduction}

A dynamic simulation was conducted for the life of mine (LOM) extension project of Coal Mine A. Coal Mine A is situated in the north-eastern part of South Africa, in the Mpumalanga province and was established in 2007. The mine was designed to process 6 Million Tonnes (MT) of 

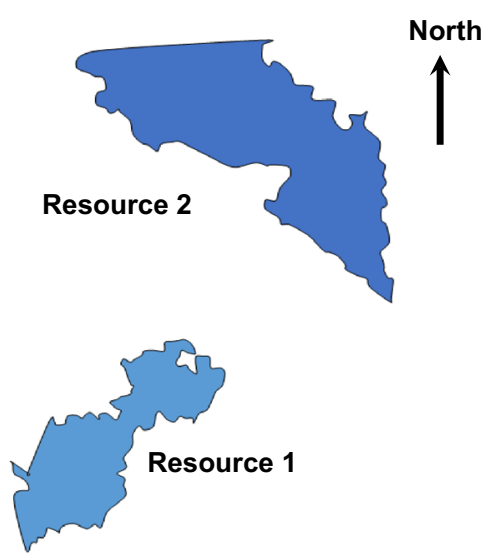

Fig. 1 Coal mine a resources proximity. Note The distance between Resource 1 and 2 are not to scale

Run of Mine (ROM) from Resource 1 (shown in Fig. 1), and it had a LOM of approximately 11 years. Resource 2, located approximately $7 \mathrm{~km}$ away, was identified as a means of extending the LOM. The LOM extension project commenced in 2011 and has since been implemented.

A surface (terrace) mining operation was planned to be established at the new mine. Cast blast, rollover dozing, and truck and shovel mining processes was planned to be used to remove overburden material to expose the various coal horizons. Coal excavation was planned to be conducted using truck and shovel processes. The system which was simulated was the coaling operation from the mine, a new Bulk Materials Handling (BMH) system, which tied into an existing BMH system and the existing Dense Medium Separation (DMS) Plant (shown in Fig. 2).

The mine and the BMH system were designed such that the critical constrained resource (CCR) in the system, the Dense Medium Separation (DMS) Plant, can process an average of 5.8 Million Tonnes Per Annum (Mtpa) (including 5\% moisture) of coal from the new reserve. A dynamic simulation was required to provide the project review team with the assurance that the materials handling value chain (from mining face to rail load-out station) can deliver 5.8 Mtpa.

\section{Significance of research}

Williams (2004) stated that it is important to learn from the mistakes made on historical projects, such that the same mistakes on current and future projects can be avoided. However, project post-mortems are rarely conducted. Anbari et al. (2008) discussed the role of post-project reviews which improve organisational performance and increase competitiveness over the long term. Mills (1985) indicated that a post-installation appraisal is an effective management tool. One of the project review deliverables is a comparison of actual performance against management expectations. The results of the appraisal are useful in improving mine performance. The dynamics of process operations are often not considered in process engineering and in the development of operating procedures for new facilities (Bonem 2013). Giovanni et al. (2017) stated that one of the most significant risks of a mining project is that it does not deliver production in line with the volumes committed in the project investment proposal. Mining companies have been investigating opportunities to reduce production costs through efficiency improvements, maximising equipment availabilities, and better planning (Roberts 2002). To achieve these objectives, dynamic simulation software is used as an input into the design and planning of both surface and underground operations. There is limited information available on actual mine performance versus planned, post project investment.

During the LOM extension project study phases of Coal Mine A, Modelling and Simulation (M\&S) was conducted.

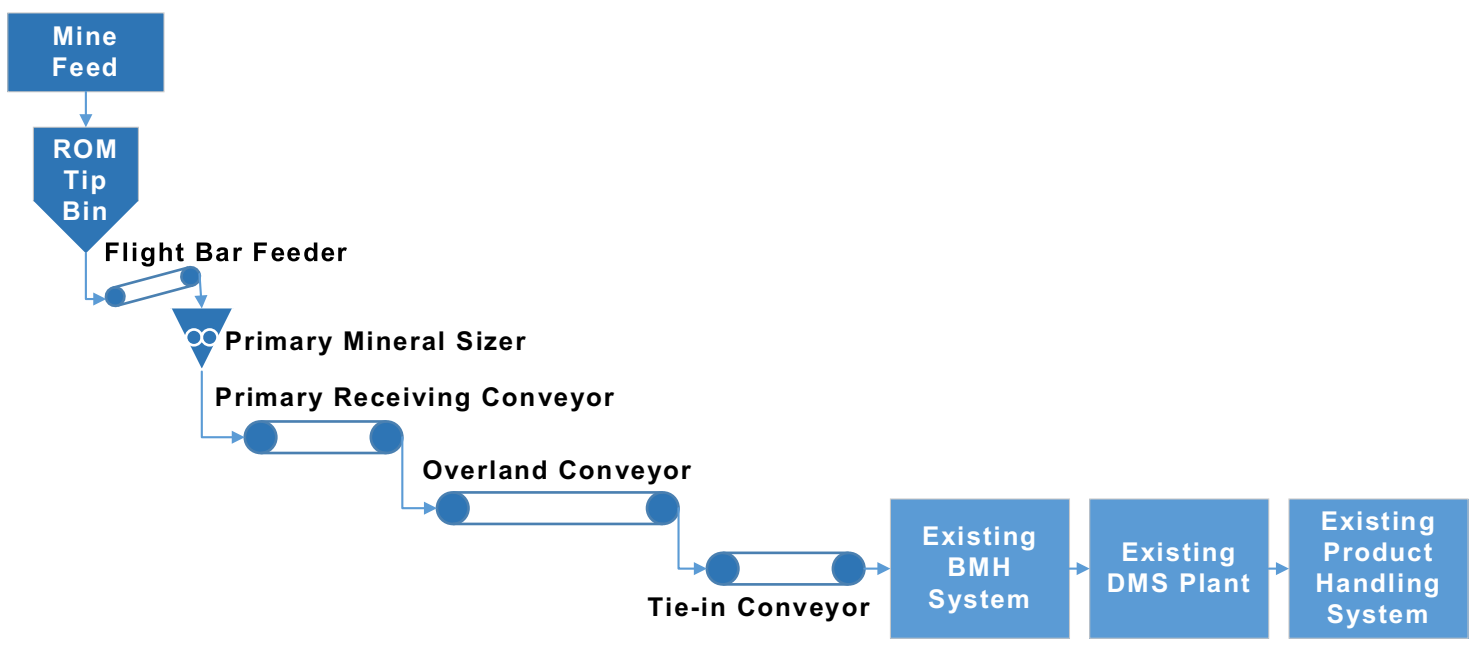

Fig. 2 System overview 
There was an element of risk associated with the dynamic simulation itself because the approach was new. It was confirmed telephonically that this specific surface mine materials handling value chain simulation approach is new and has not been used previously by mining conglomerates such as Anglo American Coal, Glencore and Sasol in South Africa. The need to validate the simulation was paramount, as this work could make a significant contribution to the mining industry, and stress the importance of validation and post project appraisals.

\section{Mining simulation history}

Modelling and Simulation (M\&S) in the mining industry has a notable history. Computer simulation has increased in popularity since the 1960s, and a large amount of research has been conducted to make simulation reliable and pragmatic (King 2012). The first mining simulation was conducted by Rist (1961) using Symbolic Programming System Language. Using the simulation, Rist (1961) calculated the optimal number of trains required for a haulage level at an underground molybdenum mine. During the 1960s, many mining simulations were built using a computer language called Fortran (Sturgul 2000). At the time, Fortran was an inefficient way of programming due to the use of punched cards, which made both the writing and debugging of programs very time-consuming. Falkie and Mitchell (1963) conducted research at an underground coal mine in Pennsylvania, United States of America on a rail haulage system. This work contributed to the use of Monte Carlo simulation methods in stochastic simulation models. Sanford (1965) was the first to simulate a belt conveying system in Fortran successfully. Morgan and Peterson (1968) developed a stochastic simulation of a surface mining operation. Bauer and Calder (1972) used the General Purpose Simulation System (GPSS) to simulate the load-haul-dump mining activity for open pit mines. GPSS was used by Steiker (1982) to simulate the rail haulage system of an underground mine. Wilson (1984) described the use of GPSS to simulate the rail transport of ore from platinum mines in Africa. Hancock and Lyons (1984) described a computer simulation package known as SIMBELT4, which was used to calculate the production at specified points in a belt conveying system, and to approximate the tonnage of ore in each storage bunker. A BMH G2 simulation (shown in Fig. 3) was completed at Sasol's Twistdraai Coal Mine (Turner 1999), which was used to optimise the coal transport, stacking, blending and beneficiation plant designs.

Herbst et al. (2012) used MetroProSim to simulate a mineral processing plant (shown in Fig. 4) and recommended that simulations include the impact of discrete

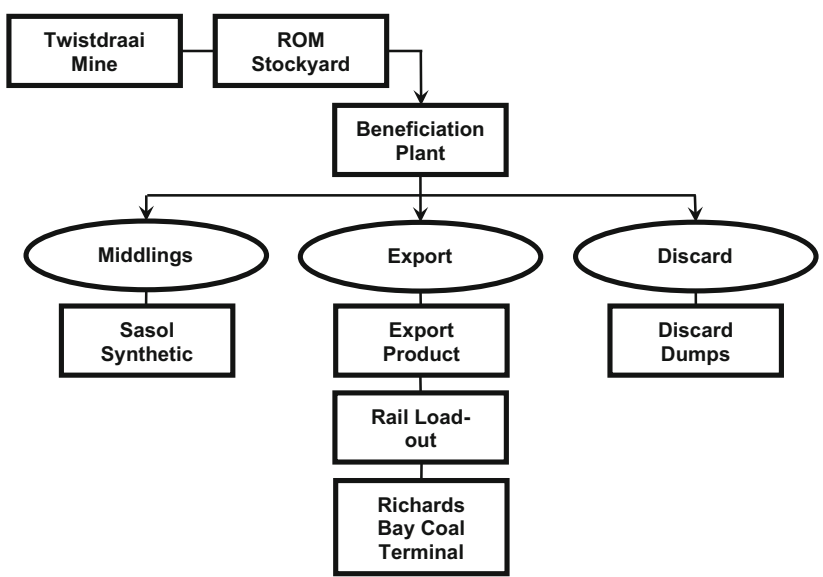

Fig. 3 Twistdraai project processes (Turner 1999)

stochastic events, such as scheduled and unscheduled maintenance which made it possible to analyse the relationships between availability, equipment sizes, and plant capacity.

Camargo et al. (2018) proposed a Method of Integrated Process Simulation and used it to simulate the production chain of an iron ore operation. The modelling method considered the dynamic, stochastic and systemic characteristics of the operation. The research conducted on the history of simulation in the mining industry confirmed that the simulation approach and method described in this paper has not been previously used.

\section{Simulation and validation}

\subsection{Model description}

The model shown in Fig. 5 consisted of three sub-systems namely Mining, BMH and DMS Plant. The Product Handling sub-system was not included in the simulation and a static capacity analysis was conducted.

As shown in Fig. 5, a representation of the materials handling value chain was set up in the Gensym G2 expert system development environment. The consulting company which was utilised, had a G2 simulation specialist resource who had conducted similar G2 simulations for other clients. Therefore, the decision was taken to utilise G2 for the simulation. The inputs and outputs of the simulation are summarised in Fig. 6.

\subsection{Simulation assumptions}

There were various assumptions made in the model which were applicable to instances where the model would differ from the operation of the system in reality. These assumptions simplified the modelling process and had a 


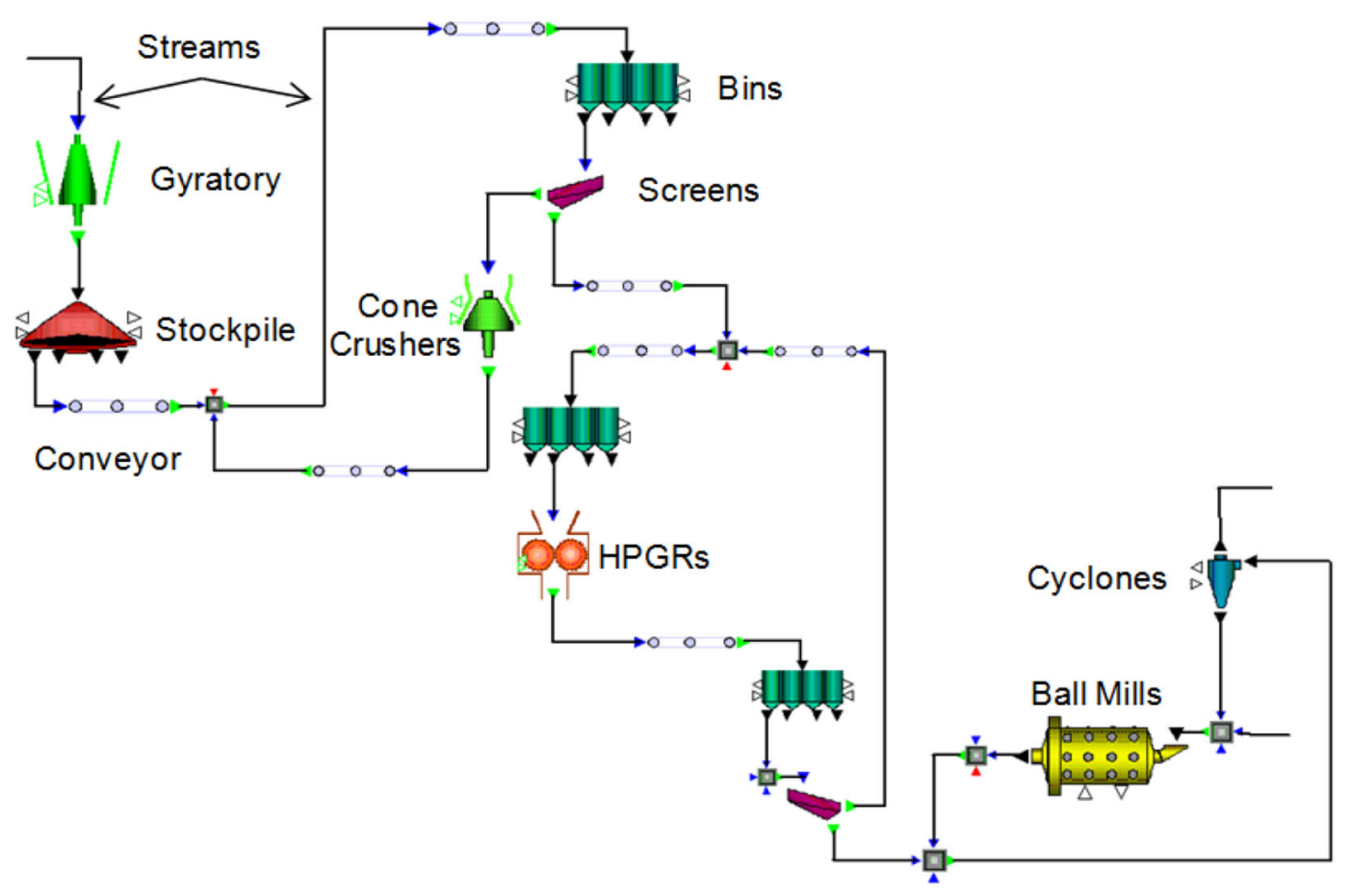

Fig. 4 MetroProSim plant flowsheet (typical) (Herbst et al. 2012)

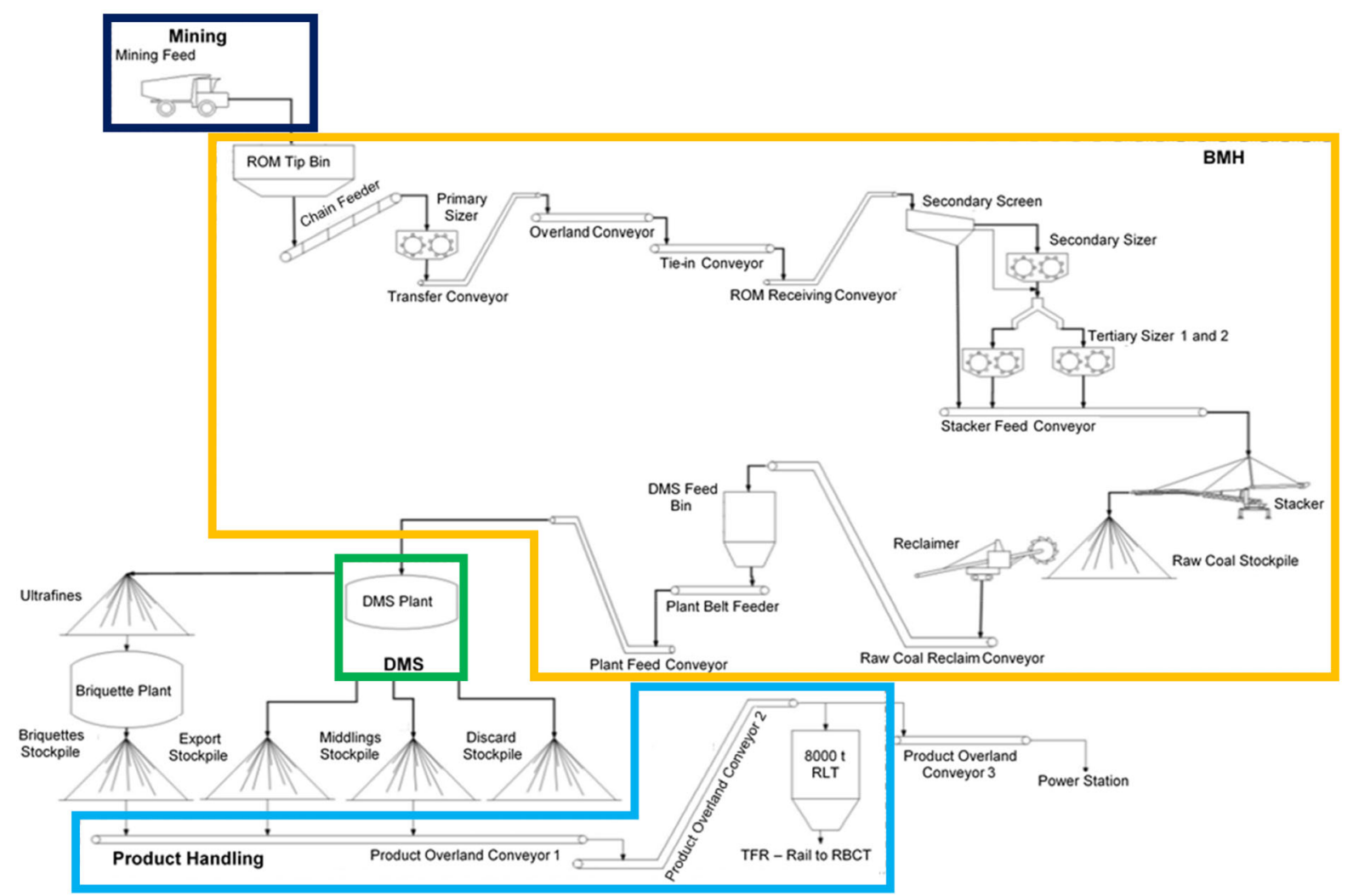

Fig. 5 Simulation overview 


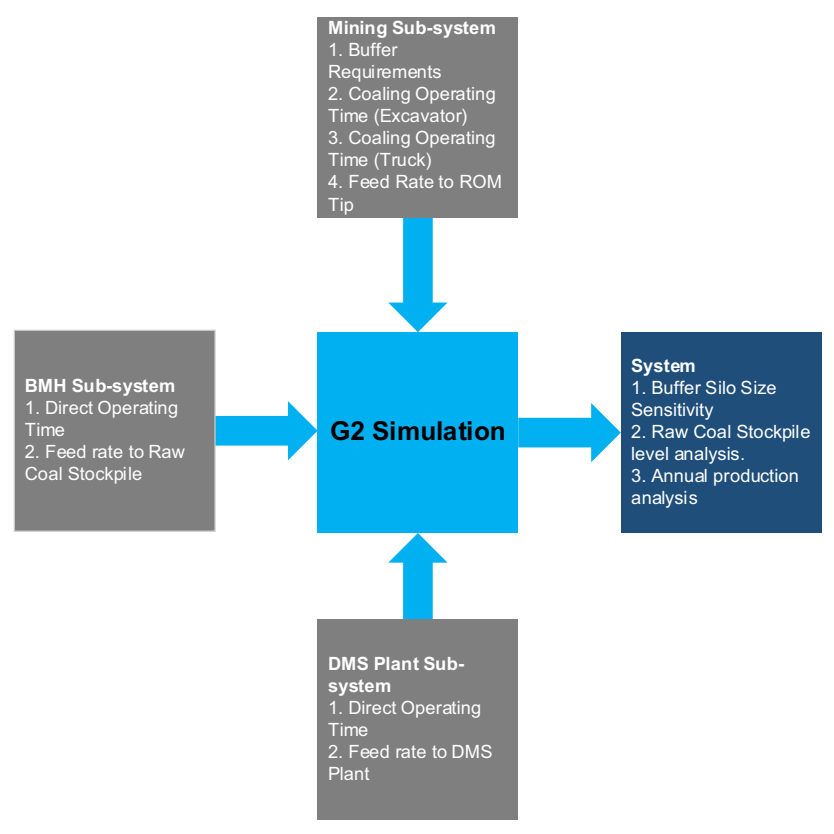

Fig. 6 G2 Simulation inputs and outputs

negligible impact on the results of the simulation. The assumptions include:

- All components, with the exception of the ROM Tip Bin, run at constant rates. Ramp-up and ramp-down rates at start-up and shutdown are not applicable;

- No in-flight material occurs. When material is introduced into a component, it is immediately moved to the next component; and

- Particle Size Distribution (PSD) of material is not applicable.

\subsection{Simulation validation data collection}

Data was acquired from the mine over a 4-month period from June 2018 to September 2018, post project commissioning which was completed in May 2018. The sources of data include the mine survey department, the Minfo system, the BMH and DMS Plant downtime database, and the Supervisory Control and Data Acquisition (SCADA) system. The Minfo system was the repository for mining equipment and production data. All BMH system and DMS Plant instrumentation data, for example, conveyor belt scale readings, were stored in the SCADA system database. Many discussions were held with mine personnel to ensure that the data received was understood and interpreted correctly.

\subsection{Simulation inputs of the mining sub-system and validation}

The mining inputs include the mining activity buffer requirements, the number of available hours, and the feed rate to the ROM Tip.

\subsubsection{Buffer requirements}

\section{(1) Overview}

The mine plan of Coal Mine A was based on TOC principles (shown in Fig. 7), developed by Goldratt (2004). The TOC is aimed at achieving continuous improvement in a process of five steps.

The use of TOC principles in mine plan development provides the assurance in a project feasibility phase that the planned mining schedule is achievable in a practical mining environment. With active buffer management and sufficient pit length, it is possible for Coal Mine A to deliver 5.769 Mtpa. The feed rate to the ROM Tip, which was a BMH G2 Simulation Model input, assumed that the required mining activity buffers were in place. A Palisade @RISK Monte Carlo Simulation was developed which aimed to identify the required mining activity buffer capacities or inventory.

\section{(2) Simulation description}

The current mine process buffers and operating rules were used in the development of the simulation of the new mine. The simulation used the mine production figures of the XPAC Solutions model and a set of unique probability distributions. The probability distributions were derived from real-time operational data obtained from the current operation which describes the daily Direct Operating Time (DOT) per piece of equipment. The probability distributions aimed to mimic the typical behaviour of each equipment type. The DOT for each production day was calculated by multiplying the average required operating



Fig. 7 Steps in TOC cycle (Lean and Six Sigma University 2018) 
hours per day with the specific seeding result. A seeding is one part of the simulation where every distribution function is populated with a unique value according to the shape of the applicable distribution. Figure 8 shows the buffer lengths $(\mathrm{a}-\mathrm{i})$ of sequential mining activities of a typical surface (terrace) coal mining operation.

The simulation generated the lengths of the buffers of each of the different mining activities to ensure that no interference occurs between interdependent activities. The probability of successful production was evaluated in terms of pit length. The detailed levels pertaining to the red, yellow and green buffer levels which were calculated in Palisade@Risk are shown in Table 1.

\section{(3) Validation data collection}

The mine survey department conducted regular aerial surveys such that the buffer lengths for each of the different mining activities can be recorded. Each aerial photo (170 in total) circulated during the validation period (1 June 2018-30 September 2018) was analysed. Buffer lengths were measured off the aerial photos and recorded in Microsoft Excel.

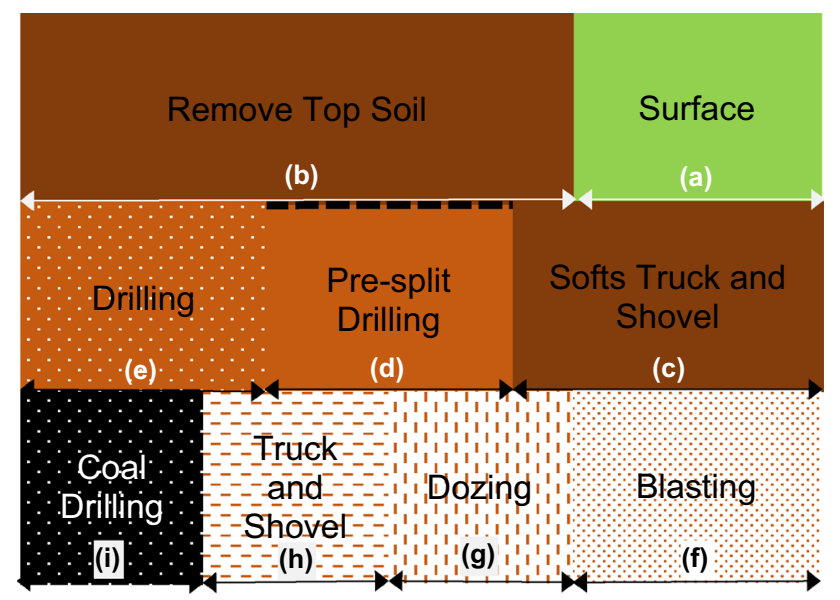

Fig. 8 Mining activity (top soil removal to coal drilling) buffers of a typical surface (terrace) coal mining operation

\section{(4) Validation data analysis}

The actual buffer lengths were compared to the recommended red, yellow and green buffer lengths in Table 1 . In the graphs that follow the blue line represents the actual buffer. Figure 9 shows the drill pad buffer analysis. The drilling of the hard burden activity buffer analysis is shown in Fig. 10.

The drilling pad buffer operated above the green buffer and was, therefore, sufficient for the validation period. The drilling activity buffer was predominantly below the red level. In the last week of September 2018, the buffer showed signs of improvement and rose above the yellow level, but then dropped again to the red level. Similarly, the blasted (hard burden) to be pushed activity buffer was analysed and identified to operate on $0 \mathrm{~m}$ for most of the time. When the buffer was above the $0 \mathrm{~m}$ level, it was still below the red buffer level. The insufficient buffer had an impact on the buffer for the dozing activity. For the month of June 2018, no dozer linear buffer existed. The buffer level then picked up and operated predominantly below the yellow buffer level. There was a period of only \pm 10 days

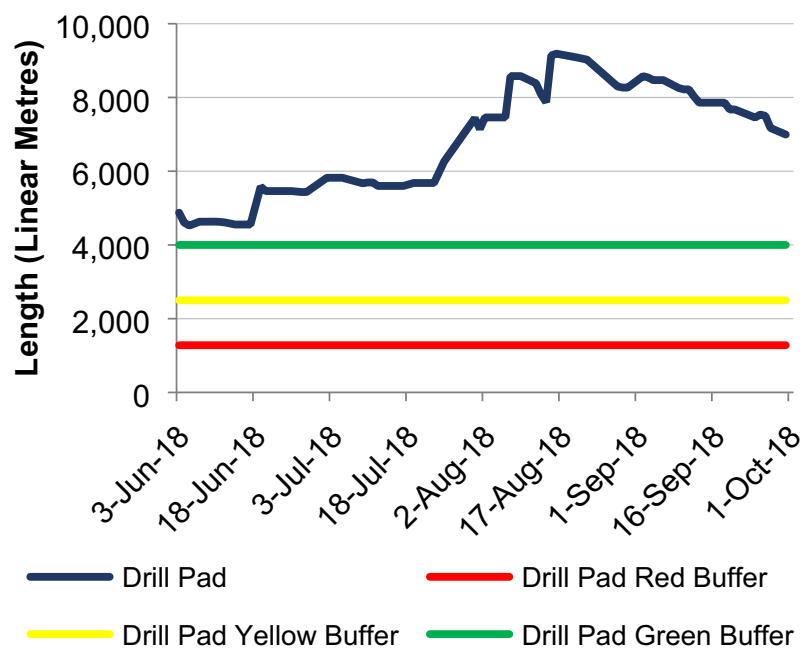

Fig. 9 Drill pad buffer

Table 1 Proposed detail buffer lengths

\begin{tabular}{llccc}
\hline Material horizons & Activity & Red buffer $(\mathrm{m})$ & Yellow buffer $(\mathrm{m})$ & Green buffer $(\mathrm{m})$ \\
\hline Softs & Drill pad & 1280 & 2500 & 4000 \\
Hard burden & Drilled & 500 & 750 & 1800 \\
Hard burden & Blasted to be pushed & 500 & 750 & 1440 \\
Hard burden & Dozer linear & 180 & 300 & 1440 \\
Hard burden & Bench linear & 255 & 450 & 1080 \\
Nos. 2 and 1 seam & Coal exposed & 500 & 850 & 1440 \\
Nos. 2 and 1 seam & Coal mined not on floor & 405 & 750 & 1080 \\
\hline
\end{tabular}




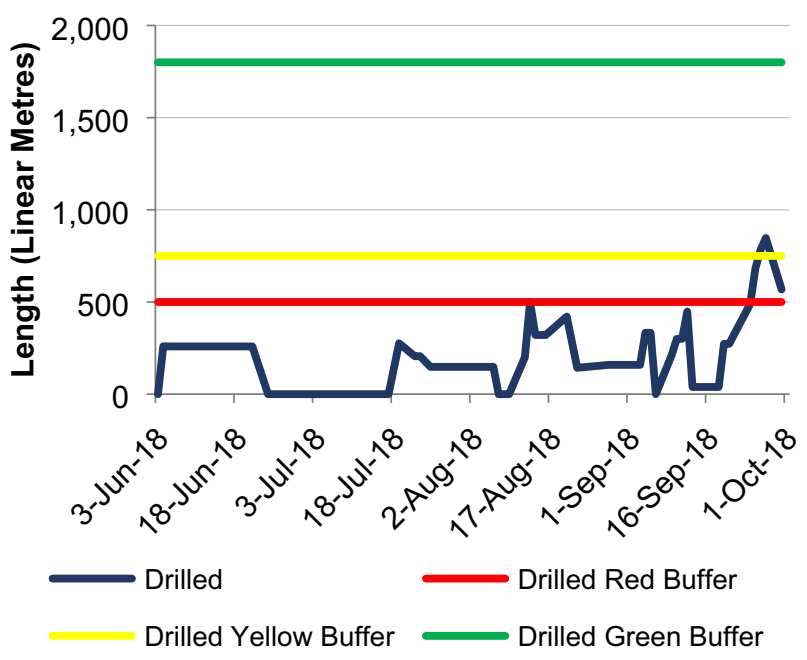

Fig. 10 Drilled buffer

in which the buffer was between the yellow and the green zones.

The bench liner (truck and shovel of hard burden) activity buffer analysis revealed that the buffer was sufficient for the duration of the validation period. It was also identified that there was a sufficient amount of coal exposed. The mine could have achieved an adequate coal exposed buffer by assigning the truck and shovel fleet to move the hard burden which was originally intended to be blasted and dozed. The hard burden could have been soft enough not to require drilling and blasting. The coal mined not on floor or the truck and shovel of coal activity buffer analysis revealed that the buffer was insufficient for most of the time ( \pm 14 weeks), apart from a period of \pm 2 weeks when the buffer operated between the green and yellow zones. The reason for this could be that the truck and shovel capacity for coaling was assigned to the truck and shovel activity for hard burden, instead of using drilling and blasting and then dozing. Another reason could be poor coal drilling performance, which impacted the buffer available for the truck and shovel of coal.

\subsubsection{Coaling operating time (Hitachi EX3600 Excavator)}

The short-term coaling plan was based on the number of days the BMH system was available (shown in Table 2). The 305 days which the BMH system was available was used in the mine variable feed rate input file, which was used by the G2 Simulation.

The hours available (planned) for the mine Hitachi EX3600 Excavator were calculated in Table 3 using historical data from 2014, 2015 and 2016 (Quarter 1). In the mine variable feed rate input file, which was used by the G2 Simulation, the available hours was limited to $5798 \mathrm{~h}$.

\section{(1) Validation data collection}

The raw data used to compile Table 3 [Percentage of $8760 \mathrm{~h}$ (planned)] was analysed, and downtime codes per category were noted. A new dataset was obtained from the mine and the downtime codes were then allocated to the different categories in a similar fashion as conducted previously. The sum totals for the different categories were then computed per excavator, using an MS Excel Pivot table. An average of the hours for the two excavators were calculated which led to the compilation of the values in the percentage of $8760 \mathrm{~h}$ (actual) column (shown in Table 3).

\section{(2) Validation data analysis}

There was no downtime booked to "Not Scheduled to Produce", although there were 3 days of public holidays during the validation period. Uncontrollable Events (14\%) was more than double the previous allowance (6\%). DOT was calculated to be $4 \%$ lower than the previous calculation. The CAT 994 FEL was used 23\% of the time more than estimated previously. This resulted in the COT being $19 \%$ higher than the previous estimate as a result of the unplanned usage of the CAT 994 FEL.

Table 2 BMH operating days per year

\begin{tabular}{|c|c|c|c|c|c|}
\hline No. & Description & Days & Percent base $(\%)$ & Comments & Calculation \\
\hline A & Calendar time & 365 & 100 & Total days per year & \\
\hline $\mathrm{B}$ & Public holidays & 13 & 4 & Average (2014 and 2015) & \\
\hline $\mathrm{C}$ & Uncontrollable events & 20 & 5 & Adverse weather & \\
\hline $\mathrm{D}$ & Total controllable time & 332 & 91 & & $\mathrm{~A}-\mathrm{B}-\mathrm{C}$ \\
\hline $\mathrm{E}$ & Normal scheduled maintenance & 20 & 5 & $9 \mathrm{~h}$ once a week & $365 / 7 \times 9 / 24$ \\
\hline $\mathrm{F}$ & Extended scheduled maintenance & 2 & 1 & $12 \mathrm{~h}$ shut every 4 weeks & $365 / 28 \times 3 / 24$ \\
\hline G & Annual scheduled maintenance & 5 & 1 & 5-day annual shut & \\
\hline $\mathrm{H}$ & Total scheduled maintenance & 27 & 7 & & $E+F+G$ \\
\hline I & Available days & 305 & 84 & & $\mathrm{D}-\mathrm{H}$ \\
\hline
\end{tabular}


Table 3 Mining coaling operating time (COT) calculation

\begin{tabular}{|c|c|c|c|c|c|c|}
\hline No. & Description & Hours & $\begin{array}{l}\text { Percentage of } 8760 \mathrm{~h} \\
\text { (planned) }(\%)\end{array}$ & Comments & Calculation & $\begin{array}{l}\text { Percentage of } \\
8760 \text { h (actual) }(\%)\end{array}$ \\
\hline A & Total time & 8760 & 100 & Total calendar time per year & $365 \times 24$ & 100 \\
\hline B & $\begin{array}{l}\text { Not scheduled to } \\
\text { produce }\end{array}$ & 309 & 4 & $\begin{array}{l}\text { Average number of public } \\
\text { holidays ( } 2014 \text { and 2015) }\end{array}$ & $12.88 \times 24$ & 0 \\
\hline $\mathrm{C}$ & Uncontrollable events & 566 & 6 & $\begin{array}{l}\text { Time lost due to adverse weather } \\
\text { and labour disruptions }\end{array}$ & $23.57 \times 24$ & 14 \\
\hline $\mathrm{D}$ & Controllable time & 7885 & 90 & & $\mathrm{~A}-\mathrm{B}-\mathrm{C}$ & 86 \\
\hline $\mathrm{E}$ & $\begin{array}{l}\text { Unscheduled } \\
\text { maintenance }\end{array}$ & 595 & 7 & $\begin{array}{l}\text { Time taken to fix machine after } \\
\text { breakdowns }\end{array}$ & $\begin{array}{l}\text { Calculated from } \\
\text { historical data }\end{array}$ & 6 \\
\hline $\mathrm{F}$ & $\begin{array}{l}\text { Scheduled } \\
\text { maintenance }\end{array}$ & 794 & 9 & & $\begin{array}{l}\text { Calculated from } \\
\text { historical data }\end{array}$ & 12 \\
\hline G & Operational stops & 232 & 3 & $\begin{array}{l}\text { Route deviations, refueling and } \\
\text { process interruptions }\end{array}$ & $\begin{array}{l}\text { Calculated from } \\
\text { historical data }\end{array}$ & 2 \\
\hline $\mathrm{H}$ & Uptime & 6264 & 72 & & D-E-F-G & 66 \\
\hline I & Operational indirect & 216 & 2 & Time required for shift changes & $\begin{array}{l}\text { Calculated from } \\
\text { historical data }\end{array}$ & 2 \\
\hline $\mathrm{J}$ & $\begin{array}{l}\text { Operational delays } \\
\quad \text { (unplanned) }\end{array}$ & 247 & 3 & Ad hoc delays & $\begin{array}{l}\text { Calculated from } \\
\text { historical data }\end{array}$ & 3 \\
\hline $\mathrm{K}$ & $\begin{array}{l}\text { Operational delays } \\
\text { (planned) }\end{array}$ & 352 & 4 & Pre-shift checks & $\begin{array}{l}\text { Calculated from } \\
\text { historical data }\end{array}$ & 5 \\
\hline $\mathrm{L}$ & Unclassified & 246 & 3 & Trucks were unavailable & $\begin{array}{l}\text { Calculated from } \\
\text { historical data }\end{array}$ & 0 \\
\hline M & DOT & 5202 & 59 & & $\mathrm{H}-\mathrm{I}-\mathrm{J}-\mathrm{K}-\mathrm{L}$ & 55 \\
\hline $\mathrm{N}$ & $\begin{array}{l}\text { Use of CAT } 994 \\
\text { during maintenance }\end{array}$ & 596 & 7 & & Allowance & 30 \\
\hline $\mathrm{O}$ & COT & 5798 & 66 & & $\mathrm{M}+\mathrm{N}$ & 85 \\
\hline
\end{tabular}

\subsubsection{Coaling operating time (Komatsu 730e Truck)}

The mining hours per year were limited to $5798 \mathrm{~h}$, dictated by the available time for the Hitachi EX3600 Excavator (shown in Table 3). The time per day available to the trucks for coaling was calculated and used in the mine variable feed rate input file, which was used by the G2 Simulation. For 2014, 2015 and 2016 Quarter 1, the best uptime the trucks achieved was $20.4 \mathrm{~h}$ in 1 day. It was difficult to separate the coal from the overburden truck information because each truck was used interchangeably. A maximum DOT of $21 \mathrm{~h}$ per day for a dedicated fleet of coal trucks was used. Thus, $3 \mathrm{~h}$ of no coal per day $(1.5 \mathrm{~h}$ at the start and end of each 12-h shift) was incorporated into the mining input file in the G2 simulation. The total hours lost to mining shift changes was calculated as follows:

$$
\begin{aligned}
\text { Mining shift changes } & =3 \text { hours per day } \times 305 \text { days } \\
& =915 \text { hours }
\end{aligned}
$$

In the G2 simulation, 915 lost hours were scheduled on the mining truck fleet only, which was a consequential lost time event on the BMH system (Table 7).

\section{(1) Validation data collection}

Downtime data for the five Komatsu 730e Trucks from the mine's Minfo system was analysed. The best uptime the trucks achieved, and the average is shown in Table 4. The average of the top 10 DOT the trucks achieved for the validation period was calculated to be $20.3 \mathrm{~h}$.

\section{(2) Validation data analysis}

The average of the top 10 best uptime the trucks achieved $(20.3 \mathrm{~h})$ was within $0.5 \%$ of the calculation conducted in the LOM extension project feasibility phase (20.4 h).

\subsubsection{Feed rate to the ROM tip}

The mining operation is a single loading fleet, with a maximum loading rate of $1263 \mathrm{t} / \mathrm{h}$ which is the rate that could be achieved by one excavator when fully trucked (four trucks). The maximum loading rate was calculated using Talpac software. Trucks were used interchangeably between the CAT 994 FEL and the Hitachi EX3600 Excavator. The mine did not record the allocation of trucks 
Table 4 Komatsu 730e Truck hours achieved per day from June 2018 to September 2018 (top 10 performance)

\begin{tabular}{lll}
\hline Truck number & Date & DOT (h) achieved \\
\hline ODT001 & 22-Sep-18 & 20.16 \\
ODT002 & 26-Aug-18 & 20.24 \\
ODT002 & 21-Sep-18 & 20.34 \\
ODT003 & 18-Jun-18 & 20.09 \\
ODT003 & 26-Aug-18 & 20.24 \\
ODT003 & 06-Sep-18 & 20.16 \\
ODT003 & 07-Sep-18 & 20.16 \\
ODT003 & 25-Sep-18 & 20.06 \\
ODT004 & 26-Aug-18 & 20.24 \\
ODT005 & 13-Aug-18 & 21.32 \\
Average & & 20.30 \\
\hline
\end{tabular}

to each specific excavator or loader. It was, therefore, not possible to verify from historical operational data what the achievable mine production was for each of the excavators and the loader. Therefore, the performance of the Hitachi EX3600 Excavator and the CAT 994 FEL was assumed to be the same. The input file for the G2 simulation was generated in Palisade@RISK. Palisade @RISK generated 10 sets, each containing 1000 iterations of typical production days in each set. Each day consisted of random feed rates within a typical 21-hour day experienced on the mine. The feed rate was programmed not to exceed $1263 \mathrm{t} /$ $\mathrm{h}$ and to fall within a feed to ROM Tip probability distribution which was generated using historical data. Palisade @RISK automatically incorporated unplanned stops (hours with zero tonnes) per day using historical Mean Time To Repair (MTTR) data for the excavators from 2014 to 2015. Palisade@RISK was programmed to select 365 days within each set of 1000 days. The 365 days within a specific set that were likely to yield the average yearly scheduled production of $6 \mathrm{Mtpa}$ were selected for input into the G2 simulation. To integrate the Palisade @ RISK model outputs into the $\mathrm{G} 2$ model, a variable production input was incorporated into the G2 model, in accordance with the variable mining feed. The mining input file provided probable mine feed distributions per day, for a period of 365 days. The $\mathrm{G} 2$ simulation then discounted the mining feed inputs, depending on ROM Tip availability, utilising the following discounting factors, which led to a total of 88 days lost over the year:

- Rain delays (20 days in total simulated over the year);

- Annual 5-day shut;

- Public holidays (13 days in total simulated to occur on actual annual date);
- BMH scheduled maintenance events (21 days in total simulated over the year); and

- BMH unscheduled maintenance events (29 days in total simulated over the year).

Table 5 shows the potential mine production outcomes based on the capability of the coal mining fleet which was calculated in Palisade @RISK. P(1) represents the lowest (1\%) probability of success and $\mathrm{P}(95)$ represents the highest $(95 \%)$ probability of success.

At a $95 \%$ confidence level (P95), the average production over a 21 -h shift was calculated to be $937 \mathrm{t} / \mathrm{h}$, resulting in production of $19684 \mathrm{t}$ per day. The simulation indicates that over 305 days, the coal that could be delivered to the ROM Tip could range between $14243 \mathrm{t}$ and $23786 \mathrm{t}$ per day, with the most likely production being $19684 \mathrm{t}$ per day.

\section{(1) Validation data collection}

Information in the Minfo database indicated the time each truck spent on coaling and overburden related activities. The total DOT and the total coaling time for the trucks were compared (Fig. 11). Figure 12 shows the same comparison for the excavators and FEL.

The total DOT for the trucks was $8200 \mathrm{~h}$ and the total coaling time for the trucks was $3701 \mathrm{~h}$. The trucks were used, on average $45 \%$ of the DOT for coaling-related activities. Excavators and trucks were used interchangeably between overburden- and coaling-related activities and not used as proposed during the project feasibility study. The total DOT was $4338 \mathrm{~h}$ and the total coal loading time was $1787 \mathrm{~h}$ (42\% of DOT) for the excavators and FEL.

The number of loaders used on coaling activities and the average production $(\mathrm{t} / \mathrm{h})$ achieved was analysed. The average production achieved was $569 \mathrm{t} / \mathrm{h}$. The mine was designed to use a single excavator or loader on coal. The data confirmed that there was a deviation from the mine plan. The following results are the peak production achieved per excavator or loader combination:

- One excavator and/or FEL = $1263 \mathrm{t} / \mathrm{h}$;

- Two excavators and/or FEL $=1739 \mathrm{t} / \mathrm{h}$; and

- Two excavators and FEL $=1502 \mathrm{t} / \mathrm{h}$.

The production information for the mine was calculated from the Minfo system data (Figs. 13, 14).

The average daily production was $8101 \mathrm{t}$. The three highest mine production days were 1 September 2018 (19350 t), 19 September 2018 (21300 t), and 25 September 2018 (21600 t). The mine performance was below the average monthly target production, as can be seen in Fig. 14. Mine production was continuously improved per month from June 2018 to September 2018. There was 
Table 5 Potential production of mining operation

\begin{tabular}{llll}
\hline Probability (risk) & Tonnes per year (21-hour day for 305 days) & Tonnes per day & Tonnes per hour (21 h) \\
\hline Minimum & 4344102 & 14243 & - \\
Maximum & 7254785 & 23786 & 1263 \\
$\mathrm{P}(95)$ & 6003534 & 19684 & 937 \\
$\mathrm{P}(90)$ & 6285400 & 20608 & 981 \\
$\mathrm{P}(80)$ & 6440498 & 21116 & 1006 \\
$\mathrm{P}(70)$ & 6547631 & 21468 & 1022 \\
$\mathrm{P}(60)$ & 6609891 & 21672 & 1032 \\
$\mathrm{P}(50)$ & 6686340 & 21922 & 1044 \\
$\mathrm{P}(40)$ & 6769197 & 22194 & 1057 \\
$\mathrm{P}(30)$ & 6823713 & 22373 & 1065 \\
$\mathrm{P}(20)$ & 6909351 & 22654 & 1079 \\
$\mathrm{P}(10)$ & 7009749 & 22983 & 1094 \\
$\mathrm{P}(5)$ & 7075959 & 23200 & 1105 \\
$\mathrm{P}(1)$ & 7214419 & 23654 & 1126 \\
\hline
\end{tabular}

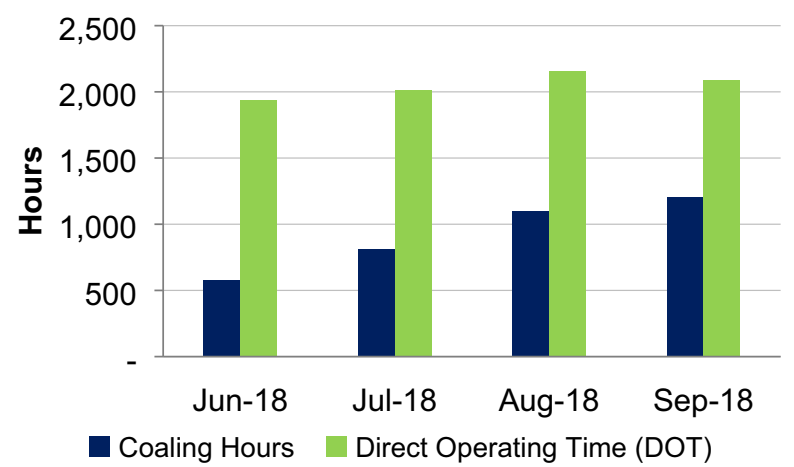

Fig. 11 Komatsu 730e Trucks

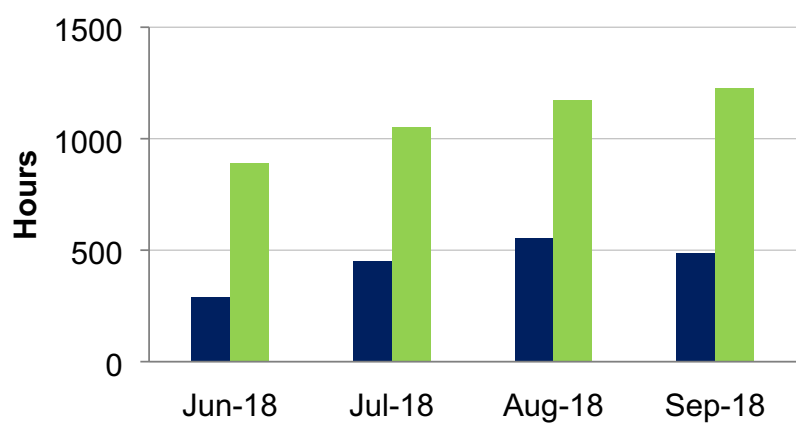

Coal Loading Hours Direct Operating TIme (DOT)

Fig. 12 Excavators and FEL

$\pm 1000000 \mathrm{t}$ produced by the mine, but the shortfall during the validation period, based on the required monthly average production to achieve $5.769 \mathrm{Mtpa}$, was $\pm 930000 \mathrm{t}$.

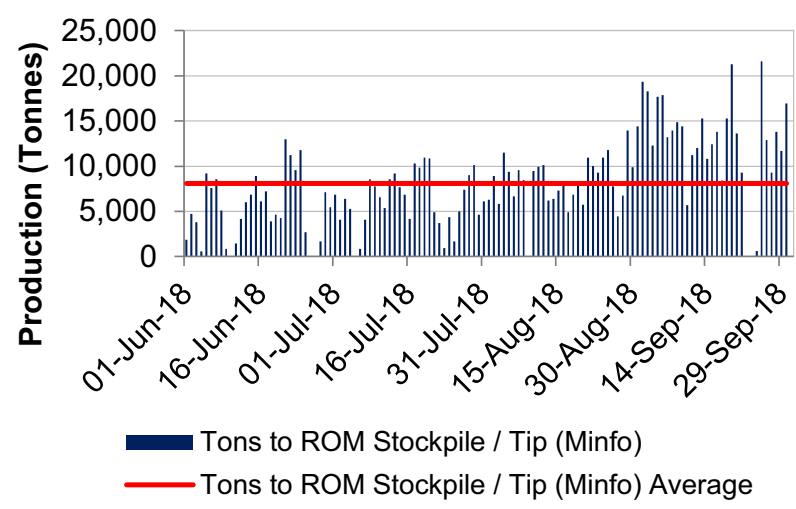

Fig. 13 Mine production from June 2018 to September 2018

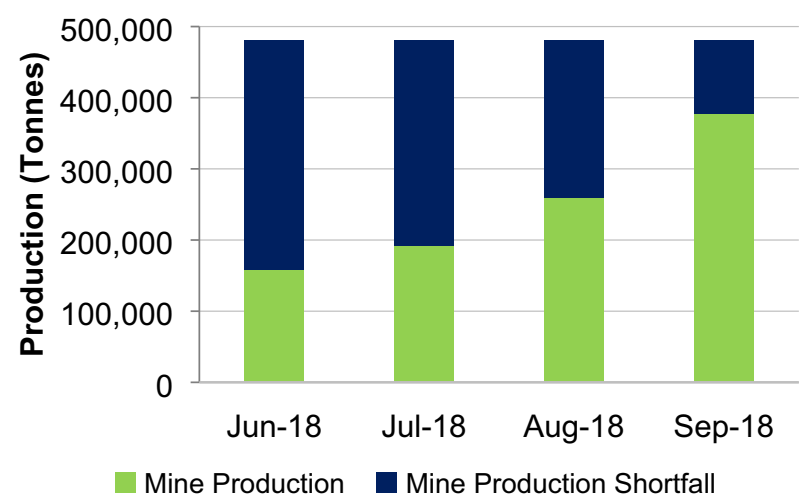

Fig. 14 Mine production performance

(2) Validation data analysis

The trucks were used $45 \%$ of the time for coaling, and the excavators and/or FEL was used $42 \%$ of the time. With 
Table 6 Actual versus planned feed rate to ROM tip

\begin{tabular}{llrr}
\hline Actual or planned & Probability (risk) & Production (t/d) & Production (t/h) \\
\hline Actual & Max & 21600 & 1263 \\
& P(95) & 8101 & 569 \\
Planned & Max & 23786 & 1263 \\
& P(95) & 19684 & 937 \\
\hline
\end{tabular}

reference to Table 6 , the mine achieved production of $1263 \mathrm{t} / \mathrm{h}$, and this is in line with the calculation conducted in the LOM extension project feasibility phase.

The highest production achieved was $1739 \mathrm{t} / \mathrm{h}$, but this was with two excavators, or with one excavator and one FEL. The intent of the mine plan was to use one dedicated excavator, and to use the FEL as a back-up machine, and not in parallel with the excavator. There were instances when the mine used both excavators and the FEL, but only achieved production of $1502 \mathrm{t} / \mathrm{h}$. The use of both excavators and the FEL in parallel on coaling activities was also not intended. The maximum tonnage the mine achieved was $21600 \mathrm{t}$, which was $10 \%$ greater than the planned tonnage at a P95 confidence level. This tonnage could be achieved consistently.

\subsection{Simulation inputs for the BMH sub-system and validation}

The BMH system inputs include the available hours and the system capacity from the mechanical design basis.

\subsubsection{DOT}

The DOT for the BMH system from the ROM Tip through to the Raw Coal Stockpile was calculated in Table 7.

\section{(1) Validation data collection}

The downtimes from 1 June 2018 to 30 September 2018 recorded by the mine were analysed. The downtimes were classified as per the time model definitions used in the project feasibility phase. After each downtime was classified, the sum totals for the different categories were computed using an Excel Pivot table as shown in Table 7.

\section{(2) Validation data analysis}

With reference to Table 7, the Not Scheduled to Produce calculation was $3 \%$ lower than the previous calculation. Uncontrollable Events was 7\% higher, which resulted in Controllable Time being 4\% lower than the previous calculation. Unscheduled and Scheduled Maintenance were within $\pm 3 \%$ of the previous estimate, but Operational Stops were $8 \%$ higher, which resulted in Uptime being $7 \%$ lower than the previous estimate. Operational Indirect was $4 \%$ lower than the previous value, which resulted in the overall DOT being $2 \%$ lower.

\subsubsection{Feed rate to raw coal stockpile}

The feed rate in the mechanical design basis of the $\mathrm{BMH}$ is summarised below:

- Nominal Production $=1022 \mathrm{t} / \mathrm{h}$. This was the average feed rate that could be sustainably supported by the system; and

- Peak Production $=1263 \mathrm{t} / \mathrm{h}$. The system was designed to run at a peak rate for limited durations for the purposes of catch-up after potential upset conditions.

The feed rate from the ROM Tip to the Raw Coal Stockpile was set at the peak of $1263 \mathrm{t} / \mathrm{h}$ in the G2 simulation for both the $5.769 \mathrm{Mtpa}$ and the $6.484 \mathrm{Mtpa}$ scenarios.

\section{(1) Validation data collection}

Production tonnages between June 2018 and September 2018 on the Minfo system were analysed. The Primary Receiving Conveyor and Stacker Feed Conveyor belt scale readings were obtained from the mine SCADA system and compared to the information on the Minfo system (Fig. 15). Figure 16 shows the tonnes per day processed by the BMH system for September 2018.

The information on Minfo correlated well with the belt scale information on the mine SCADA system (average difference of $3 \%$ ). There was a $5 \%$ average difference between the Primary Receiving Conveyor Belt Scale and the Stacker Feed Conveyor Belt Scale. The calculated production is therefore considered accurate. An average production of $331 \mathrm{t} / \mathrm{h}$ was calculated using the Primary Receiving Conveyor belt scale readings. The average production from the Stacker Feed Conveyor belt scale readings was calculated in a similar manner as $343 \mathrm{t} / \mathrm{h}$. The production difference between the Primary Receiving Conveyor and Stacker Feed Conveyor was $12 \mathrm{t} / \mathrm{h}$ (within $\pm 4 \%$ of each other). The calculated production was, therefore, at an acceptable level of accuracy. 
Table 7 BMH DOT calculation

\begin{tabular}{|c|c|c|c|c|c|c|}
\hline No. & Description & Hours & $\begin{array}{l}\text { Percentage of } \\
8760 \mathrm{~h} \text { (planned) } \\
(\%)\end{array}$ & Comments & Calculation & $\begin{array}{l}\text { Percentage of } \\
8760 \text { h (actual) } \\
(\%)\end{array}$ \\
\hline A & Total time & 8760 & 100 & Total calendar time per year & $365 \times 24$ & 100 \\
\hline $\mathrm{B}$ & $\begin{array}{l}\text { Not scheduled to } \\
\text { produce }\end{array}$ & 312 & 4 & 13 public holidays (mining time model) & $12.88 \times 24$ & 1 \\
\hline $\mathrm{C}$ & $\begin{array}{l}\text { Uncontrollable } \\
\text { events }\end{array}$ & 480 & 5 & $\begin{array}{l}\text { Time lost-adverse weather conditions } \\
\text { (consequential losses on BMH). }\end{array}$ & $20 \times 24$ & 12 \\
\hline $\mathrm{D}$ & Controllable time & 7968 & 91 & & $\mathrm{~A}-\mathrm{B}-\mathrm{C}$ & 87 \\
\hline $\mathrm{E}$ & $\begin{array}{l}\text { Unscheduled } \\
\text { maintenance }\end{array}$ & 693 & 8 & Simulated by $\mathrm{G} 2$ & $\begin{array}{l}\text { Calculated from } \\
\text { historical data }\end{array}$ & 5 \\
\hline $\mathrm{F}$ & $\begin{array}{l}\text { Scheduled } \\
\text { maintenance }\end{array}$ & 628 & 7 & & $\begin{array}{l}\text { Calculated from mine } \\
\text { maintenance } \\
\text { schedule }\end{array}$ & 5 \\
\hline G & Operational stops & 88 & 1 & Simulated by $\mathrm{G} 2$ & Simulation output & 9 \\
\hline $\mathrm{H}$ & Uptime & 6559 & 75 & & D-E-F-G & 68 \\
\hline I & $\begin{array}{l}\text { Operational } \\
\text { indirect }\end{array}$ & 915 & 10 & & Mining shift changes & 6 \\
\hline $\mathrm{J}$ & $\begin{array}{l}\text { Operational } \\
\text { delays } \\
\text { (unplanned) }\end{array}$ & 0 & 0 & & & 0 \\
\hline $\mathrm{K}$ & $\begin{array}{l}\text { Operational } \\
\text { delays } \\
\text { (planned) }\end{array}$ & 0 & 0 & & & 0 \\
\hline $\mathrm{L}$ & Unclassified & 0 & 0 & & & 0 \\
\hline M & DOT & 5644 & 64 & & $\mathrm{H}-\mathrm{I}-\mathrm{J}-\mathrm{K}-\mathrm{L}$ & 62 \\
\hline
\end{tabular}

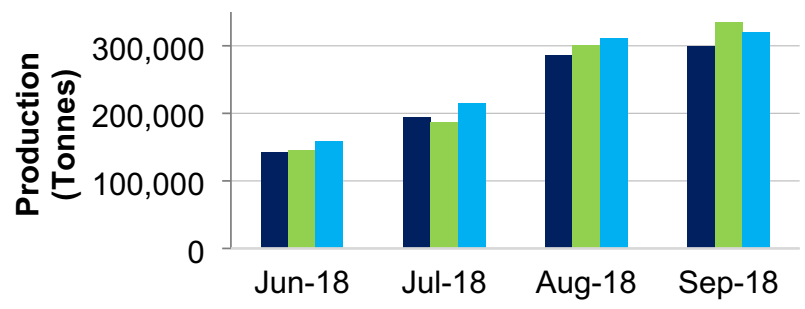

ROM (Minfo)

ROM (Primary Receiving Conveyor Belt Scale)

ROM (Stacker Feed Conveyor Belt Scale)

Fig. 15 ROM tonnes comparison (Minfo vs. conveyor belt scales)

\section{(2) Validation Data Analysis}

Table 8 shows a comparison between the actual versus planned feed rate to Raw Coal Stockpile.

The Primary Receiving Conveyor belt scale average production recorded during the validation period was $34 \%$ of the nominal $(1022 \mathrm{t} / \mathrm{h})$ planned capacity of the BMH system as a result of low mining production. The planned peak capacity of $1263 \mathrm{t} / \mathrm{h}$ was achieved in practice. Figure 16 shows that on one specific day, $\pm 20000 \mathrm{t}$ was

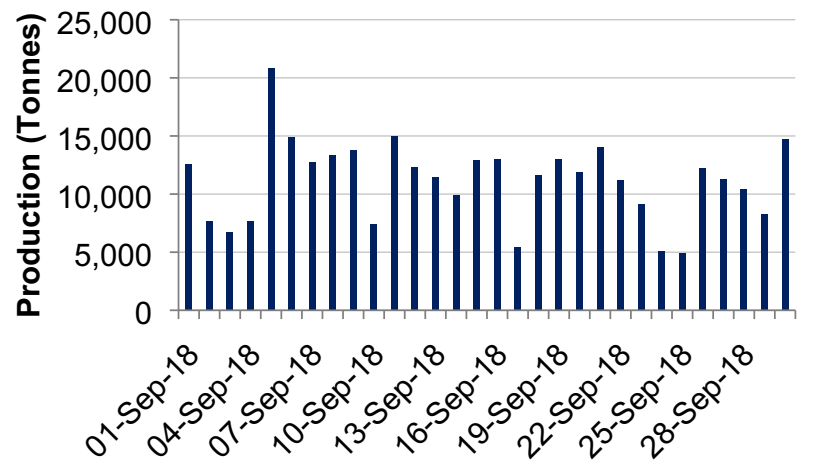

Fig. 16 BMH tonnes per day processed during September 2018

Table 8 Actual versus planned feed rate to raw coal stockpile

\begin{tabular}{llc}
\hline Actual or planned & Probability (risk) & Production $(\mathrm{t} / \mathrm{h})$ \\
\hline Actual & Max. & $>1263$ \\
& $\mathrm{P}(95)$ & 343 \\
Planned & Max. & 1263 \\
& $\mathrm{P}(95)$ & 1022 \\
\hline
\end{tabular}


achieved, which confirms that the BMH system can process the nominal daily production from the mine (19684 t).

\subsection{Simulation inputs for the DMS plant sub-system and validation}

The hours available to the DMS Plant and the nominal and peak capacities based on the capacity analysis were simulation inputs.

\subsubsection{DOT}

The DOT for the DMS Plant was calculated as described in Table 9 using historical downtime data (2011-2015). The downtimes from the initial years of Coal Mine A's operation were not reported in the current time model format and judgement was used to allocate the reported downtime to the appropriate downtime categories.

\section{(1) Validation data collection}

The downtimes from 1 June 2018 to 30 September 2018 recorded by the mine were analysed in a similar manner as the $\mathrm{BMH}$. The same process as the BMH was used to record and document the downtimes.

\section{(2) Validation data analysis}

The actual versus planned downtimes were compared (Table 9). No time was allocated to Not Scheduled to Produce as opposed to the $3 \%$ allocated in the previous exercise. There were no Uncontrollable Events booked compared to the $1 \%$ allocation made previously. This resulted in Controllable Time being 3\% higher than previous $(96 \%)$. There were large variances in Unscheduled Maintenance $(6 \%)$, Scheduled Maintenance (6\%), and Operational Stops $(15 \%)$ compared to the previous calculations. Although large, the variances had a negligible impact on the Uptime difference, which was $1 \%$. Operational Indirect was $6 \%$ higher than previous, which resulted in DOT being $4 \%$ higher than the previous estimate.

\subsubsection{Feed rate to DMS plant}

The DMS Plant had a production capacity of 6 Mtpa, $896 \mathrm{t} / \mathrm{h}$ Air dry (ad), which was based on the previous reserve ore metallurgical characteristics. A capacity analysis was conducted to determine the achievable production from the new reserve, summarised in Table 10. This formed the basis for the ROM targets.

Table 9 DMS DOT calculation

\begin{tabular}{|c|c|c|c|c|c|c|}
\hline No. & Description & Hours & $\begin{array}{l}\text { Percentage of } \\
8760 \mathrm{~h} \text { (planned) } \\
(\%)\end{array}$ & Comments & Calculation & $\begin{array}{l}\text { Percentage of } \\
8760 \text { h (actual) } \\
(\%)\end{array}$ \\
\hline A & Total time & 8760 & 100 & Total calendar time per year & $365 \times 24$ & 100 \\
\hline B & $\begin{array}{l}\text { Not scheduled to } \\
\text { produce }\end{array}$ & 288 & 3 & $\begin{array}{l}12 \text { public holidays instead of } 13 \text { as } \\
\text { used by mining and BMH }\end{array}$ & $12 \times 24$ & 0 \\
\hline $\mathrm{C}$ & $\begin{array}{l}\text { Uncontrollable } \\
\text { events }\end{array}$ & 32 & 0 & $\begin{array}{l}\text { No adverse weather impacts due to } \\
45000 \text { t raw coal stockpile }\end{array}$ & $\begin{array}{l}\text { Calculated from } \\
\text { historical data }\end{array}$ & 1 \\
\hline $\mathrm{D}$ & Controllable time & 8440 & 96 & & $\mathrm{~A}-\mathrm{B}-\mathrm{C}$ & 99 \\
\hline $\mathrm{E}$ & $\begin{array}{l}\text { Unscheduled } \\
\text { maintenance }\end{array}$ & 917 & 10 & Simulated by $\mathrm{G} 2$ & $\begin{array}{l}\text { Calculated from } \\
\text { historical data }\end{array}$ & 4 \\
\hline $\mathrm{F}$ & $\begin{array}{l}\text { Scheduled } \\
\text { maintenance }\end{array}$ & 507 & 6 & & $\begin{array}{l}\text { Calculated from mine } \\
\text { maintenance schedule }\end{array}$ & 0 \\
\hline G & Operational stops & 199 & 2 & $\begin{array}{l}\text { Hours reported as DOT by G2, } \\
\text { above the } 6700 \text { h design basis }\end{array}$ & Simulation output & 17 \\
\hline $\mathrm{H}$ & Uptime & 6817 & 78 & & D-E-F-G & 79 \\
\hline I & $\begin{array}{l}\text { Operational } \\
\text { indirect }\end{array}$ & 117 & 1 & $\begin{array}{l}\text { Extended planned maintenance } \\
\quad(2014 \text { and 2015) }\end{array}$ & $\begin{array}{l}\text { Calculated from } \\
\text { historical data }\end{array}$ & 7 \\
\hline $\mathrm{J}$ & $\begin{array}{l}\text { Operational } \\
\text { delays } \\
\text { (unplanned) }\end{array}$ & 0 & 0 & & & 0 \\
\hline $\mathrm{K}$ & $\begin{array}{l}\text { Operational } \\
\text { delays } \\
\text { (planned) }\end{array}$ & 0 & 0 & & & 0 \\
\hline $\mathrm{L}$ & Unclassified & 0 & 0 & & & 0 \\
\hline M & DOT & 6700 & 76 & & H-I-J-K-L & 72 \\
\hline
\end{tabular}


Table 10 Feed to plant (new reserve) scenarios

\begin{tabular}{lllll}
\hline Probability (risk) & FTP (t/h ad) & Annual tonnes (ad) & FTP (t/h including 5\% moisture) & Annual tonnes (including 5\% moisture) \\
\hline Plant maximum & 922 & 6175000 & 968 & 6484000 \\
Average annual & 820 & 5494000 & 861 & 5769000 \\
Low FTP possibility p2.5 & 748 & 5012000 & 785 & 5259500 \\
\hline
\end{tabular}

Performance tests were completed on the Raw Coal Stockpile Reclaimer during which it was established that the Reclaimer could only deliver $948 \mathrm{t} / \mathrm{h}$, as measured on the DMS Plant Feed Conveyor belt scale. This was significantly below the original design capacity, however, under normal conditions, the Reclaimer recovery rate could exceed the required nominal FTP (Feed To Plant) of $861 \mathrm{t} /$ h. With reference to Table 10, the feed rate from the Raw Coal Reclaim Conveyor to the DMS Plant was set at $861 \mathrm{t} /$ $\mathrm{h}$ for the 5.769 Mtpa scenario and $968 \mathrm{t} / \mathrm{h}$ for the 6.484 Mtpa scenario in the G2 simulation.

\section{(1) Validation data collection}

FTP information was obtained from the Minfo system. The Plant Feed Conveyor Belt Scale readings were also obtained from the mine SCADA system. ROM Contractor (Minfo) represents the ROM volumes mined, crushed and supplied to the DMS Plant from the existing mine. These ROM volumes were fed onto the Stacker Feed Conveyor via a temporary material handling system. This information was compared in Fig. 17.

There were two sources of ROM supplied to the DMS Plant from the existing and new mines. The ROM volumes from the existing mine comprised $38 \%$ of the FTP on average. There was an average of $1 \%$ difference between the Minfo information and the Feed To Plant Conveyor Belt Scale readings. Figure 18 shows the actual production of the DMS Plant compared with the monthly average target $(480750 \mathrm{t})$ required to meet the yearly production target of 5.769 Mtpa. The DMS Plant did not run at capacity during the validation period, and production was $28 \%$ below the $480750 \mathrm{t}$ average target per month to meet 5.769 Mtpa (Fig. 18). Figure 19 shows the tonnes per day processed by the DMS Plant for September 2018. The

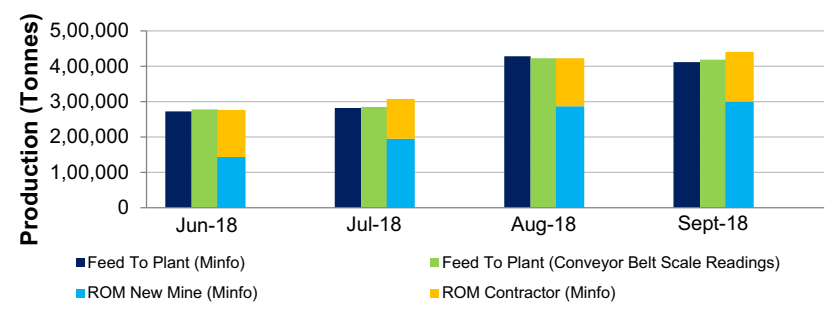

Fig. 17 DMS plant feed tonnage comparison

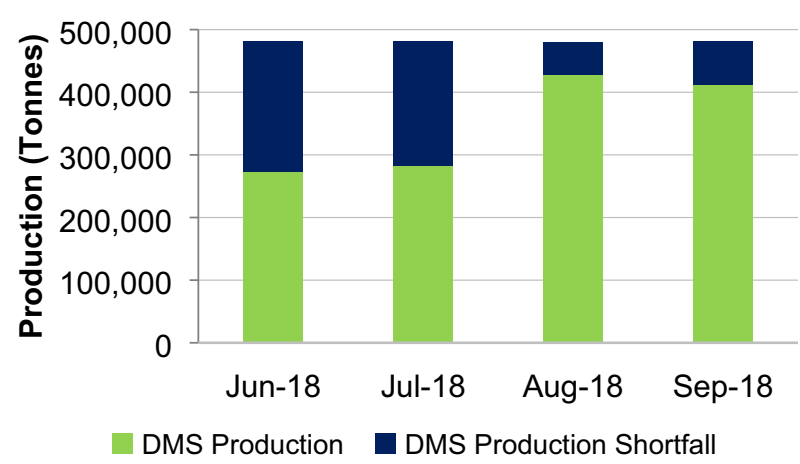

Fig. 18 DMS plant production performance

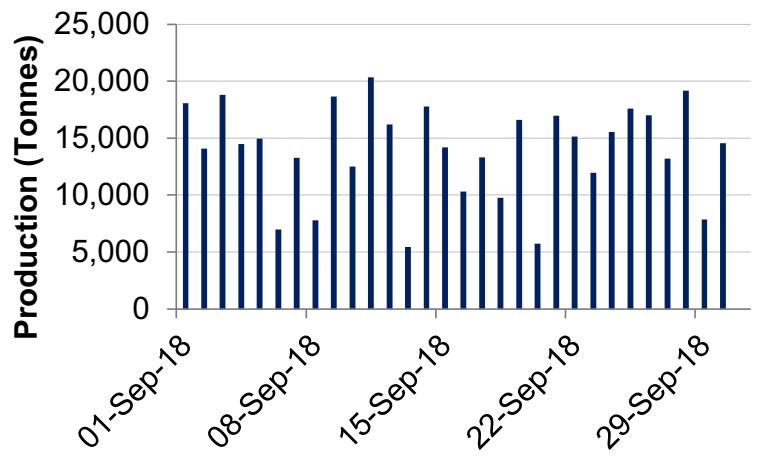

Fig. 19 DMS plant tonnes per day processed during September 2018

DMS Plant did achieve $\pm 20000 t$ in September 2018. The average production from the Feed to Plant belt scale readings was calculated to be $479 \mathrm{t} / \mathrm{h}$.

(2) Validation data analysis

In Table 11, the actual versus planned feed rate to the DMS Plant was compared.

Table 11 Actual versus planned feed rate to DMS plant

\begin{tabular}{llc}
\hline Actual or planned & Probability (risk) & Production $(\mathrm{t} / \mathrm{h})$ \\
\hline Actual & Max. & $>968$ \\
& $\mathrm{P}(95)$ & 479 \\
Planned & Max. & 968 \\
& $\mathrm{P}(95)$ & 861 \\
\hline
\end{tabular}


The average production achieved during the validation exercise was $479 \mathrm{t} / \mathrm{h}$ which was $56 \%$ of the nominal rate $(861 \mathrm{t} / \mathrm{h})$. However, a few instances were identified in which the DMS Plant exceeded the peak rate of $968 \mathrm{t} / \mathrm{h}$. The peak reclaimer rate of $948 \mathrm{t} / \mathrm{h}$ was also exceeded.

\subsection{G2 simulation outputs}

The simulation outputs include a production sensitivity analysis on the exclusion of a Buffer Silo and the inclusion of Buffer Silos of various sizes. The level of the raw coal stockpile was also analysed with or without a $3000 \mathrm{t}$ Buffer Silo. The ability of the mine to meet the annual production targets was a key consideration.

\subsubsection{Buffer Silo size}

A Buffer Silo was added into the system between the Primary Receiving Conveyor and the Overland Conveyor (shown in Fig. 20), and the G2 simulation was run with Buffer Silos of different size configurations.

From the results of the G2 simulation shown in Fig. 21, it was identified that various Buffer Silo sizes did not contribute to increased annual production tonnages. The difference between the achievable annual production with no Silo and Silos of different sizes was negligible.

The variances in production for the different Silo sizes were comparable to the statistical variance $( \pm 30000 t)$ of the G2 model.

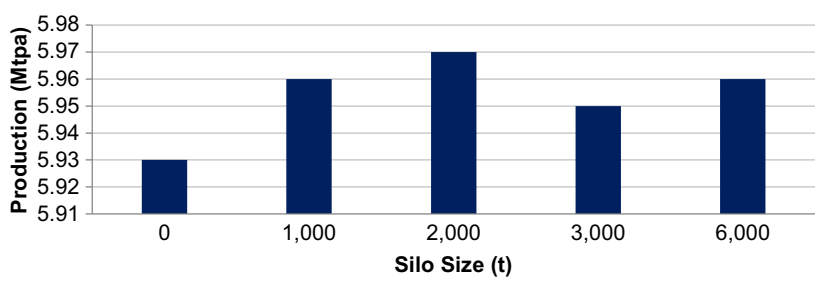

Fig. 21 Production (Mtpa) versus Buffer Silo size-G2 simulation results

\subsubsection{Raw coal stockpile level}

The Raw Coal Stockpile level (based on a live maximum capacity of $45000 \mathrm{t}$ ) was analysed in the G2 simulation with and without a $3000 \mathrm{t}$ Buffer Silo. Figure 22 shows the Raw Coal Stockpile level without a 3000 t Buffer Silo and Fig. 23 shows the Raw Coal Stockpile level with a $3000 \mathrm{t}$ Buffer Silo.

The current Raw Coal Stockpile capacity was sufficient to allow the annual target of 5.769 Mtpa to be achieved without a Silo. The full stockpile capacity is $60000 \mathrm{t}$, but there was approximately $15000 \mathrm{t}$ of "stagnant" stockpile capacity required to sustain plant feed rates and to reduce fragmentation. The $0 \mathrm{t}$ level in Figs. 22 and 23 represents 15000 t. Many coal mining operations make use of Silos, and although there are similarities, each system is unique. For this reason, benchmarking was not conducted to validate the decision on whether to include a Silo. The G2 simulation, being an acceptable industry standard, was setup with actual plant information such that it can accurately mimic the proposed system.

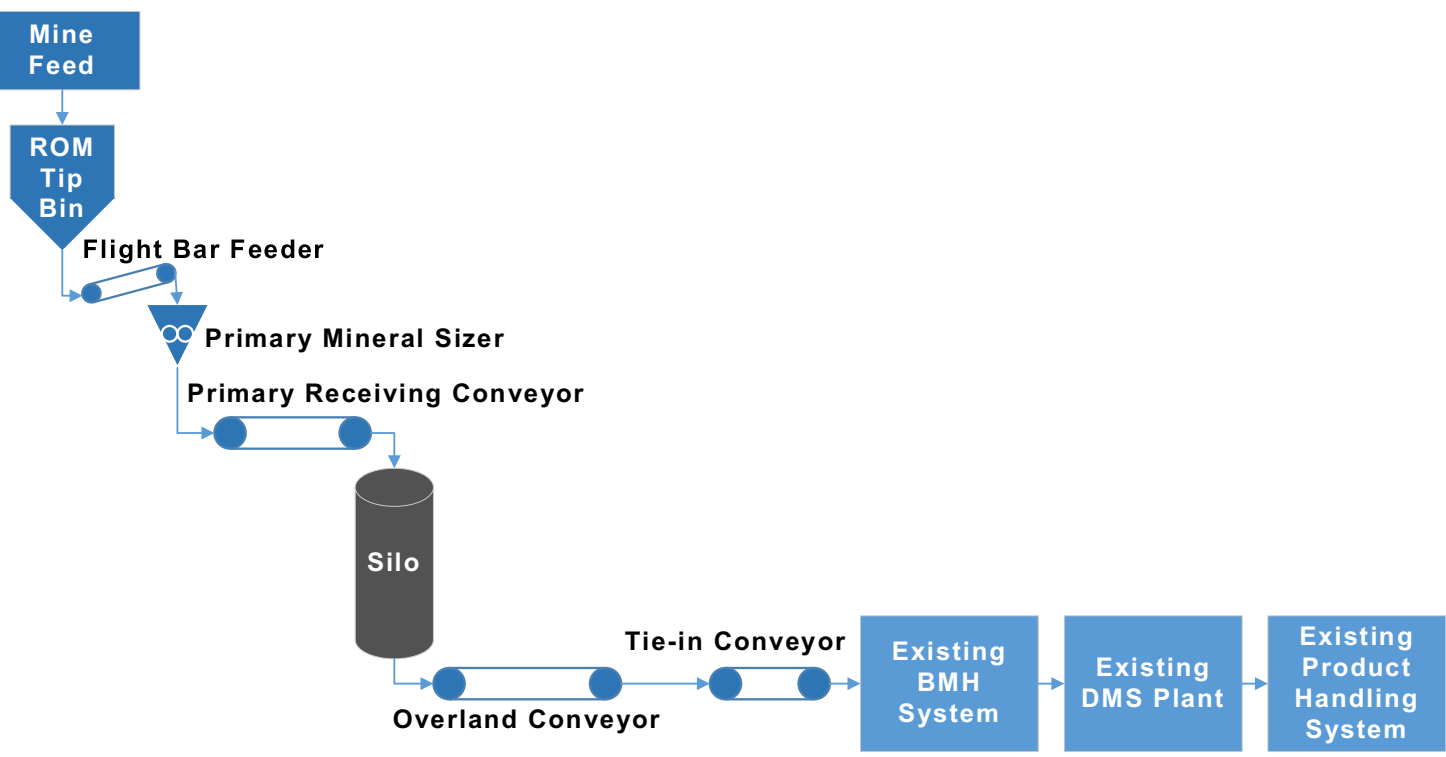

Fig. 20 BMH system with buffer Silo included 


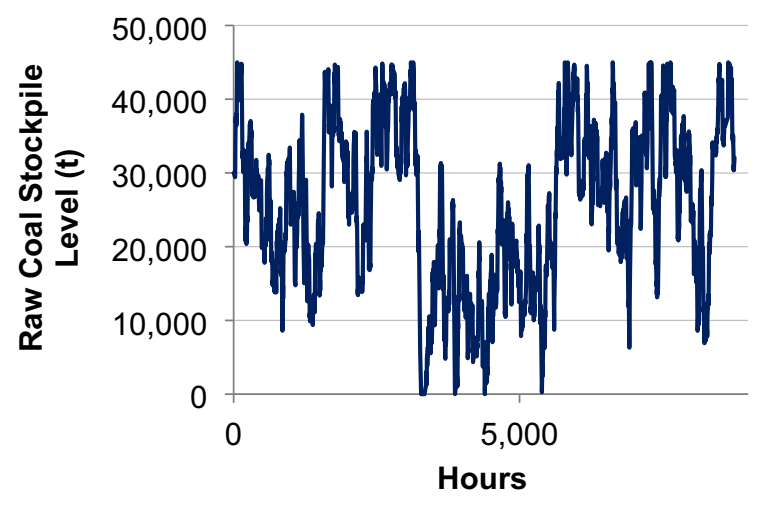

Fig. 22 DMS 861 t/h, no Silo

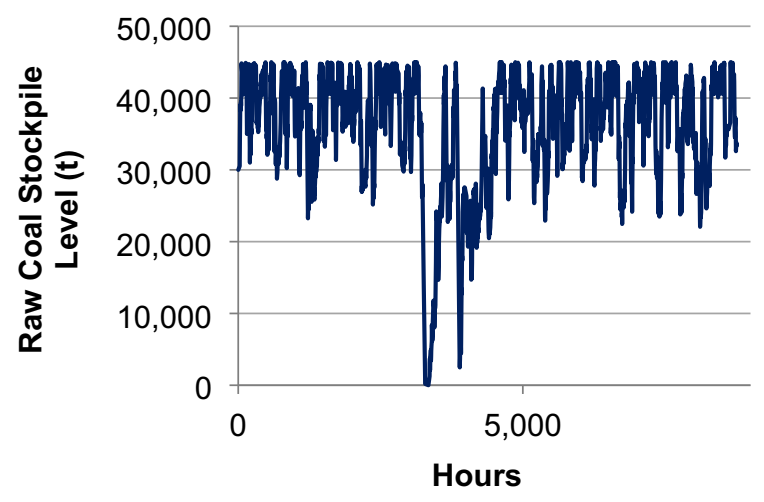

Fig. 23 DMS 861 t/h, 3000 t Silo

\subsubsection{Annual production targets}

Two scenarios (shown in Tables 12,13) were generated in the G2 simulation to establish whether the annual targets of 5.769 Mtpa and 6.484 Mtpa can be achieved. Each scenario was run for 10 times.

The results indicated that both the $5.769 \mathrm{Mtpa}$ and 6.484 Mtpa annual targets can be achieved without a
$3000 \mathrm{t}$ Silo. The system could achieve 5.93 Mtpa with a $\mathrm{P}(95)$ mine feed, and 6.53 Mtpa with a $\mathrm{P}(70)$ mine feed. A further investigation was conducted to determine the potential increase in BMH DOT if a $3000 \mathrm{t}$ Silo was constructed. The Front End up-time increased by $118 \mathrm{~h}$ due to the Silo "buffering" the nuisance trips on the downstream components. However, there was no guarantee that the mining operation would utilise the 118 additional hours. The cost to construct the Silo is approximately R44 million. This, coupled with no Net Present Value benefit, justifies the elimination of the $3000 \mathrm{t}$ Silo option.

\subsubsection{G2 simulation outputs validation}

\section{(1) Validation data collection}

The mine production information from Minfo together with the readings from the Primary Receiving Conveyor Belt Scale and the Feed To Plant Belt Scale were analysed collectively. The top $20 \%$ of the production figures from each system were identified in Table 14. The ROM volumes supplied by the Contractor utilised at the existing mine was also considered.

\section{(2) Validation data analysis}

The mine and the DMS Plant performed the best collectively on 1 September 2018 processing $\pm 19000 \mathrm{t}$ and $\pm 18000 \mathrm{t}$ respectively (Table 14). The BMH system processed $\pm 13000 \mathrm{t}$ on this specific day, but is capable of processing in access of $20000 \mathrm{t}$, as shown in Fig. 16. Table 15 shows a comparison between the planned and actual average production of each sub-system.

The difference between the average production from the mine and the BMH system was compensated through the use of a temporary ROM Stockpile which was not part of the project plan and scope. The DMS Plant ran at higher production than the BMH system as the feed to the DMS

Table 12 5.769 Mtpa target scenario

\begin{tabular}{lllll}
\hline Scenario & Mine feed (Mtpa) & DMS rate (t/h) & BMH rate (t/h) & Achieved production (Mtpa) \\
\hline Base case & $\mathrm{P}(95)$ & 861 & 1263 & 5.93 \\
Base case (3000 t Silo included) & $\mathrm{P}(95)$ & 861 & 1263 & 5.95 \\
\hline
\end{tabular}

Table 13 6.484 Mtpa Target Scenario

\begin{tabular}{lllll}
\hline Scenario & Mine feed (Mtpa) & DMS rate (t/h) & BMH rate (t/h) & Achieved production (Mtpa) \\
\hline Base case & $\mathrm{P}(70)$ & 968 & 1263 & 6.53 \\
Base case (3000 t Silo included) & $\mathrm{P}(70)$ & 968 & 1263 & 6.70 \\
\hline
\end{tabular}


Table 14 Best combination of production figures between the mine, BMH and DMS systems

\begin{tabular}{lllll}
\hline Date & ROM stockpile/tip $(\mathrm{t})$ & Primary receiving conveyor $(\mathrm{t})$ & FTP conveyor $(\mathrm{t})$ & ROM contractor $(\mathrm{t})$ \\
\hline 25-Aug-18 & 11777 & 14952 & 21087 & 6384 \\
01-Sep-18 & 19350 & 12599 & 18062 & 7239 \\
09-Sep-18 & 14400 & 13780 & 18648 & 3857 \\
12-Sep-18 & 12000 & 12340 & 16195 & 5225 \\
19-Sep-18 & 21300 & 12983 & 16593 & 4180 \\
\hline
\end{tabular}

Table 15 Sub-system average production comparison

\begin{tabular}{llcc}
\hline Actual or planned & Mine average production $(\mathrm{t} / \mathrm{h})$ & BMH average production $(\mathrm{t} / \mathrm{h})$ & DMS plant average production $(\mathrm{t} / \mathrm{h})$ \\
\hline Actual & 569 & 343 & 479 \\
Planned & 937 & 1022 & 861 \\
\hline
\end{tabular}

Plant from Resource 2 was supplemented with volumes from Resource 1 (contractor mining).

\subsection{Rail load-out station capacity analysis}

An investigation was conducted to determine if the current $\mathrm{BMH}$ and rail load-out station can process the annual product volumes. One of the main driving factors in rail load-out systems is the train arrival schedule and the typical variability associated with it. It was established that the current TFR train arrival schedules and train arrival times were highly variable. The variability in the data is of such a magnitude that utilising the variability as an input into a dynamic model to establish system capacity would not have yielded reasonable results. Therefore, a static calculation was performed which confirmed that the system has sufficient capacity.

\section{Conclusions}

The approach to the Gensym G2 dynamic simulation conducted for the Coal Mine A LOM extension project was unique and the need to validate the simulation was paramount. There were various deficiencies identified in the mining activity buffer management by Coal Mine A. One of the possible reasons for this was the unplanned use of truck and shovel capacity for overburden removal instead of the use of drilling and blasting and dozing capacity, which decreased the capacity available for the truck and shovel of coal. Another reason could be poor coal drills performance, which impacted the volume of coal available for truck and shovel. The outcome of the Hitachi EX3600 Excavator DOT validation was that the CAT 994 FEL was not used as a spare machine as originally planned and was used in parallel with the other excavators. A ROM Stockpile near the ROM Tip was not planned as per the original materials handling value chain design. A decision was taken to create the stockpile to buffer the mining processes from the $\mathrm{BMH}$ system during the commissioning period which took longer than expected. This resulted in the requirement for additional equipment capacity which could have attributed to low mining feed rates.

The average daily production that the mine produced for the validation period was poor at $8101 \mathrm{t}$, compared to the $19684 \mathrm{t}$ per day the mine was designed to produce. However, on three separate days in September 2018, the mine did achieve an average of $\pm 21000 \mathrm{t}$ which was in-line with the calculation conducted in the feasibility phase of Coal Mine A. The average production the BMH system achieved was $30 \%$ below the nominal capacity during the validation period. Nevertheless, there were instances during September 2018 when the system did run at the nominal capacity of $1050 \mathrm{t} / \mathrm{h}$, and one instance when the system processed $\pm 20000 \mathrm{t}$ in 1 day, which matched the nominal design capacity of the mine.

The continuation of the mining of Resource 1 post relocation of the mining equipment to Resource 2 was not part of the project business case. The operations team had commissioned a mining contractor to continue with the mining of Resource 1, and the DMS Plant was fed with this coal (38\% of total FTP) during the validation period. This might have been a factor in the decision not to push production from Resource 2 and could be a reason for the poor mining performance at Resource 2. Despite the alternate source of coal, the DMS Plant did not perform at capacity and meet monthly production targets. It was shown that the DMS Plant can match nominal mine design production 
$( \pm 20000 \mathrm{t} / \mathrm{d})$, when this was achieved in September 2018. The average production the DMS Plant achieved was 479 $\mathrm{t} / \mathrm{h}$, which was $56 \%$ of nominal production required to meet the annual target of 5.769 Mtpa. There were a few instances identified in which the DMS Plant exceeded the peak rate of $968 \mathrm{t} / \mathrm{h}$. The individual system components (Mine, BMH System, and DMS Plant) are individually capable of producing $\pm 20000 \mathrm{t} / \mathrm{d}$.

One of the operational performance issues identified during this case study was the buffer management of the different mining activities. The view was that, with strict buffer management, the lengths of the buffers of the different mining activities would be above the green zone (with reference to Table 1), and the full materials handling value chain will be capable of producing $\pm 20000 \mathrm{t} / \mathrm{d}$ consistently and could achieve the mine design production of $5.769 \mathrm{Mtpa}$, as predicted by the dynamic simulation. Upon commissioning, the mine was not set up in accordance with the recommendations from the TOC work conducted. It is recommended that this dynamic simulation validation be revisited and updated post the mining of Resource 1. It is further recommended that the validation exercise be conducted over a 12-month period. This will confirm beyond doubt that the approach taken for the dynamic simulation of Coal Mine A LOM extension project was accurate, effective and reliable.

Acknowledgements The work reported in this paper is part of an M.Sc. research report in the School of Mining Engineering at the University of the Witwatersrand, Johannesburg, South Africa.

Open Access This article is licensed under a Creative Commons Attribution 4.0 International License, which permits use, sharing, adaptation, distribution and reproduction in any medium or format, as long as you give appropriate credit to the original author(s) and the source, provide a link to the Creative Commons licence, and indicate if changes were made. The images or other third party material in this article are included in the article's Creative Commons licence, unless indicated otherwise in a credit line to the material. If material is not included in the article's Creative Commons licence and your intended use is not permitted by statutory regulation or exceeds the permitted use, you will need to obtain permission directly from the copyright holder. To view a copy of this licence, visit http://creativecommons. org/licenses/by/4.0/.

\section{References}

Anbari F, Carayannis E, Voetsch R (2008) Post-project reviews as a key project management competence. Technovation 28(10):633-643

Bauer A, Calder P (1972) Planning open pit mining operations using simulation. In: Applications for computers and operations research in the minerals industries (APCOM), Johannesburg, South Africa, 10-14 April 1972

Bonem J (2013) Using simplified models to simulate dynamics in process operations. Chemical Technolgy, pp. 18-20

Camargo L, Rodrigues L, Lacerda D, Piran F (2018) A method for integrated process simulation in the mining industry. Eur J Oper Res 264(3):1116-1129

Falkie T, Mitchell D (1963) Probability simulation for mine haulage systems. Trans Soc Min Eng 226:467-473

Giovanni F, Carlos C, Cindy P (2017) NPV Risk simulation of an open pit gold mine project under the O'Hara cost model by using GAs. Int J Min Sci Technol 27(3):557-565

Goldratt E (2004) The goal, 3rd edn. Goldratt Group, Faerie Glen

Hancock W and Lyons D (1984) Operational research in the planning of underground transport. In: Applications for computers and operations research in the minerals industries (APCOM), London, UK, 26-30 March 1984

Herbst J, Mular M, Pate W, Song M (2012) The next step in mineral processing plant dynamic simulations to achieve the necessary standard for prefeasibility and feasibility studies: modeling with discrete event for maintenance combined with accurate continuous process modeling. In: International mineral processing congress, New Delhi, India, 24-28 September 2012

Hoare R (2007) The role of simulation modelling in project evaluation. Australasian Institute of Mining and Metallurgy, Melbourne, Australia, 19-20 June 2007

King R (2012) Modeling and simulation of mineral processing systems, 2nd edn. Society for Mining, Metallurgy and Exploration Inc., Colorado

Lean \& Six Sigma University (2018) Lean \& Six Sigma University. https://leansixsigma.community. Accessed 3 June 2018

Mills R (1985) Theory and practice of post-installation appraisals of projects. s.l. The American Institute of Mining, Metallurgical and Petroleum Engineers

Morgan W, Peterson L (1968) Determining truck-shovel productivity. Min Eng 20:76-78

Rist K (1961) The solution of a transportation problem by use of a Monte Carlo technique. In: Applications for computers and operations research in the minerals industries (APCOM), Tucson, US, April 1961

Roberts B (2002) Computer simulation of underground truck haulage operations. Trans Inst Min Metall 111(2):123-128

Sanford R (1965) Stochastic simulation of a belt conveyor system. In: Applications for computers and operations research in the minerals industries (APCOM), Tucson, US, 16-19 March 1965

Steiker A (1982) Simulation of an underground haulage system. In: Applications for computers and operations research in the minerals industries (APCOM), Denver, US, 19-22 April 1982

Sturgul J (2000) Mine design: examples using simulation. Society for Mining, Metallurgy and Exploration Inc, Colorado

Turner R (1999) Simulation in the mining industry of South Africa. Int J Surf Min Reclam Environ 13(3):47-56

Williams T (2004) Identifying the hard lessons from projects easily. Int J Proj Manag 22(4):273-279

Wilson J (1984) Simulation of ore transport on surface rail at Impala Platinum Ltd. In: Applications for computers and operations research in the minerals industries (APCOM), London, UK, 26-30 March 1984 